\title{
Effects of egg yolk inclusion, milk replacer feeding rate, and low-starch (pelleted) or high-starch (texturized) starter on Holstein calf performance through 4 months of age
}

\author{
T. S. Dennis, F. X. Suarez-Mena, T. M. Hill, ${ }^{1}$ J. D. Quigley, and R. L. Schlotterbeck \\ Nutrition and Research Center, Provimi, Brookville, $\mathrm{OH} 45309$
}

\begin{abstract}
The objectives of this research were to evaluate milk replacer (MR) feeding rates, alternative protein and fat sources in MR, and calf starter starch concentration and their effects on calf performance to 4 mo of age. Male Holstein calves $(42.6 \pm 1.2 \mathrm{~kg}$ of body weight; $\mathrm{n}$ $=192$ ) were assigned at $3 \mathrm{~d}$ of age to 1 of 8 treatments in a randomized complete block design with a $2 \times 2 \times$ 2 factorial arrangement of treatments. Factors tested from d 0 to 56 (nursery) were low or high MR feeding rates, 0 or $10 \%$ inclusion of spray-dried egg yolks in MR, and low- or high-starch calf starter. The low MR rate was $0.66 \mathrm{~kg}$ of dry matter (DM) fed for $39 \mathrm{~d}$ followed by $0.33 \mathrm{~kg}$ of $\mathrm{DM}$ for $3 \mathrm{~d}$. The high MR rate was $0.87 \mathrm{~kg}$ of DM fed for $5 \mathrm{~d}, 1.08 \mathrm{~kg}$ of DM for $37 \mathrm{~d}$, and $0.43 \mathrm{~kg}$ of DM for $7 \mathrm{~d}$. The MR contained $27.5 \%$ crude protein and $19.6 \%$ fat (DM basis) and starters were $21.2 \%$ crude protein; low starch was a complete pellet with $10.2 \%$ starch, and high starch was textured using whole corn and oats with $43.3 \%$ starch. From d 56 to 112 (grower), calves were randomly assigned to pens (4 calves/pen) maintaining MR rate and starch content while stratifying yolk treatments within pen, resulting in a $2 \times 2$ factorial arrangement. Starter was blended with $5 \%$ chopped hay during the grower trial. Fecal scores and medical treatments were recorded daily. In the nursery trial, calves were weighed initially and weekly thereafter. Hip width and body condition score (BCS) were measured initially and every $2 \mathrm{wk}$ thereafter. In the grower trial, body weight, hip width, and BCS were measured on d 56, 84, and 112. Data were analyzed as repeated measures with calf (nursery) or pen (grower) as the experimental unit. Calf average daily gain, hip width, and BCS change were greater for calves fed high versus low MR, 0 versus $10 \%$ yolk, and high versus low starch in the nursery. In the grower trial, calves fed low MR and high starch had the great-
\end{abstract}

Received May 15, 2017.

Accepted July 28, 2017.

${ }^{1}$ Corresponding author: mhill@provimi-na.com est average daily gain (1.09 vs. $0.87 \mathrm{~kg} / \mathrm{d})$ and hip width change (5.4 vs. $3.9 \mathrm{~cm})$ compared with calves fed low MR and low starch with other treatments intermediate. From 0 to 112 d, calves fed high MR had $9 \%$ greater body weight gain and $4 \%$ greater hip width change than calves fed low MR, yet nutrient efficiency was similar despite $80 \%$ more MR intake than calves fed low MR. Additionally, calves fed high-starch starter achieved $18 \%$ greater body weight gain and $17 \%$ greater hip width than calves fed low starch starter overall, a more than 2-fold greater response than the effect of MR feeding rate.

Key words: calf, starch, egg, milk replacer

\section{INTRODUCTION}

Many have reported that as more milk or milk replacer (MR) is fed, preweaning ADG increases (Bar-Peled et al., 1997; Nocek and Braund, 1986). However, when the amount of milk or MR fed is more than approximately $0.7 \mathrm{~kg}$ of $\mathrm{DM}$, postweaning $\mathrm{ADG}$ is typically less than when $\leq 0.7 \mathrm{~kg}$ of DM from milk or MR is fed (Hill et al., 2006a,b, 2007, 2010). Reduced postweaning ADG has been thought to be related to less dry feed intake before weaning, but preweaning MR intake has shown mixed effects on DMI immediately postweaning and after $56 \mathrm{~d}$ (Hill et al., 2007, 2010, 2013). Less postweaning ADG when feeding more milk or MR may be associated with lesser rumen development (Terré et al., 2007a,b; Suarez-Mena et al., 2011), leading to less digestion of dry feed at and after weaning (Terré et al., 2007a,b; Hill et al., 2010, 2016c; Chapman et al., 2016). Some data suggest calves fed large amounts of milk to achieve more ADG early in life may increase milk yield in the first lactation (Soberon et al., 2012). Other researchers have suggested calves fed more starter and less MR to achieve more balanced early life ADG may also increase potential for more milk in the first lactation (Bach and Ahedo, 2008; Heinrichs and Heinrichs, 2011; Bach, 2012; Gelsinger et al., 2016).

Milk proteins are expensive relative to other proteins due to increased demand for human use (Davis and 
Drackley, 1998) and the use of alternative, lower cost proteins are of interest for calf MR. Egg protein has been shown to have a comparable protein efficiency ratio to milk protein (Schaafsma, 2000), could have utility in MR, and offers a lower cost than milk proteins. However, the success of using egg protein in MR for calves has been mixed. Quigley (2002) reported a linear reduction in ADG for calves fed 10 and 20\% spraydried whole egg (SDWE) as a partial replacement for whey protein and animal fat, particularly from $\mathrm{d}$ 0 to 28 when no starter was fed. However, Touchette et al. (2003) found 5\% SDWE inclusion in MR supported similar or improved ADG compared with allmilk protein, but $15 \%$ SDWE inclusion reduced ADG approximately $18 \%$ compared with lower inclusions of SDWE. It is unclear why SDWE reduces performance when partially replacing milk proteins, though it may be due to anti-nutritional factors present in egg protein (Quigley, 2002). Some of these factors may be avoided by using spray-dried egg yolk, a co-product of egg white separation for human consumption. Egg yolk is composed primarily of lipids, which make up approximately $61 \%$ of the total DM of the yolk and include palmitic acid, oleic acid, linoleic acid, and phosphotidylcholine (Quigley, 2002; USDA, 2015). Protein makes up approximately $35 \%$ of the yolk DM and includes lipoproteins and phosphoproteins (Byrne et al., 1989). Use of alternative proteins for MR fed to calves less than $3 \mathrm{wk}$ of age is advised against by NRC (2001) due to difficulties in protein digestion. However, most of the research in neonatal calves where alternative proteins were fed in MR have been with low to moderate $(0.44$ to $0.73 \mathrm{~kg}$ of DM/d) MR feeding rates and formulas with less than $24 \% \mathrm{CP}$ on a DM basis.

The use of low-starch co-products is prevalent in the US dairy calf feed market (Hill et al., 2012). Quality carbohydrates are required by the young calf because the rumen and other digestive systems are underdeveloped (NRC, 2001). Inclusion of low-starch ingredients in the diet of calves less than 4 mo of age has resulted in reductions in ADG and structural growth (Hill et al., 2008, 2012, 2016a; Suarez-Mena et al., 2011; Terré et al., 2013) likely stemming from low digestibility (Hill et al., 2016a) compared with high-starch feeds. However, these data were collected when feeding calves low to moderate MR feeding rates. Kosiorowska et al. (2011) did not observe interactions of whole milk feeding rate (3.2 vs. $6.4 \mathrm{~kg} / \mathrm{d})$ with calf starter starch content (35 vs. $11 \%$ starch on a DM basis) on the performance of male Holstein calves, but ADG was improved when milk allowance or starch content were high. It is unclear if the response would be similar when alternative proteins are used in MR.
Most studies evaluating preweaning nutrition in calves do not report performance beyond 1 to $2 \mathrm{wk}$ postweaning. Additionally, even fewer studies have evaluated potential interactions between preweaning and postweaning nutrition on growth in dairy calves. Therefore, the objectives of this research were to evaluate spray-dried egg yolk as an alternative fat and protein source in MR, MR feeding rate, and starch concentration in the starter and their potential interactions on calf performance pre- and postweaning until 4 mo of age.

\section{MATERIALS AND METHODS}

All animals were cared for as described in the Guide for the Care and Use of Agricultural Animals in Agricultural Research and Teaching (FASS, 2010). Calves were received in 4 blocks of 48 calves 5 wk apart. Calves were purchased from a commercial dairy farm and transported $3.5 \mathrm{~h}$ to the Nurture Research Center nursery in southwest Ohio. The nursery consisted of individual calf pens $(1.2 \mathrm{~m} \times 2.4 \mathrm{~m})$ with a coarse rock, tiledrained base bedded with wheat straw in a naturally ventilated barn with curtain sides and no added heat. The nursery trial (d 0 to 56) was conducted from January to July where the average ambient temperature in the nursery was $10^{\circ} \mathrm{C}$ (range from -11 to $32^{\circ} \mathrm{C}$ ) and the average relative humidity was $77 \%$ (range from 24 to $100 \%$ ). The grower trial (d 56 to 112) was conducted from March to September with an average ambient temperature of $18^{\circ} \mathrm{C}$ (ranged from -1 to $26^{\circ} \mathrm{C}$ ) and an average humidity of $80 \%$ (ranged from 24 to $100 \%$ ).

In the nursery trial, 192 male Holstein calves initially $42.6 \pm 1.16 \mathrm{~kg}$ of BW and 3 to $4 \mathrm{~d}$ of age were assigned to 1 of 8 treatments in a randomized complete block design with $2 \times 2 \times 2$ factorial arrangement of treatments. Factors tested included 2 levels of spray-dried egg yolk inclusion (0 or 10\% on as-fed basis; Ballas Egg Products Corp., Zanesville, $\mathrm{OH}), 2$ levels of MR feeding rate, and 2 levels of starch concentration in calf starter (10 or $43 \%$ starch on DM basis). The low MR rate was $0.66 \mathrm{~kg}$ of DM fed in 2 equal meals twice daily (0630 and $1400 \mathrm{~h}$ ) for $39 \mathrm{~d}$ followed by $0.33 \mathrm{~kg}$ of DM fed once daily $(0630 \mathrm{~h})$ for $3 \mathrm{~d}$. The high MR rate was $0.87 \mathrm{~kg}$ of DM fed in 2 equal meals twice daily for $5 \mathrm{~d}, 1.08 \mathrm{~kg}$ of DM for $37 \mathrm{~d}$, and $0.43 \mathrm{~kg}$ of DM fed once daily for 7 d. Milk replacers were formulated to contain $27 \% \mathrm{CP}$ and $17 \%$ fat (DM basis; Table 1) and were diluted with water to $14 \% \mathrm{DM}$ before feeding. Calf starters were formulated to provide 20\% CP (DM basis; Table 2) and were either a complete pellet (10\% starch) or textured with whole corn and whole oats ( $43 \%$ starch). Starter and water were offered for ad libitum intake throughout 
the trial. On d 56 at the start of the grower trial, calves were randomly assigned to group pens (4 calves/pen) maintaining nursery MR feeding rate and starter starch concentration while stratifying egg yolk MR treatments within pen $(2$ calves each from 0 and $10 \%$ egg yolk MR per pen). Group pens had $6.5 \mathrm{~m}^{2}$ of outside pen space and $1.4 \mathrm{~m}^{2}$ of resting area per calf within an opaque plastic hutch and the resting area was bedded with straw with no added heat. Calves were fed calf starter (same as in nursery trial) blended with 5\% chopped grass hay for ad libitum intake with unrestricted access to water.

On the day of arrival at $1600 \mathrm{~h}$ and the morning after arrival, all calves were fed $0.66 \mathrm{~kg}$ of DM from $0 \%$ yolk MR. The day after arrival at approximately 1200 $\mathrm{h}(\mathrm{d} 0)$, calves were weighed and randomly assigned to treatments. At this time, blood was sampled intravenously, serum was separated by centrifugation at 3,000 $\times g\left(\mathrm{VWR}\right.$, Batavia, IL) and $20^{\circ} \mathrm{C}$ for $15 \mathrm{~min}$, and serum total protein concentration was estimated using an optical refractometer (Atago U.S.A. Inc., Bellevue, WA). Feces were scored daily using a 1 to 5 scale with 1 being normal and 5 being watery (modified from Kertz and Chester-Jones, 2004). Fecal scores $>2$ were considered abnormal. Medical treatments were recorded daily and consisted of antibiotic treatments under veterinary supervision that were based on lethargy or rectal temperatures $>39.4^{\circ} \mathrm{C}$. Calves received oral electrolytes for diarrhea when fecal scores were $>2$; however, electrolytes were not counted as a medical treatments. Calves were weighed on d $0,7,14,21,28,35,42,49$, and 56 during the nursery trial and on d 84 and 112 of the grower trial. Body condition score (1 being thin and 5 being obese; modified from Wildman et al., 1982 by palpating the transverse processes of the spine by one experienced technician) and hip widths were measured with a caliper on d 0,14, 28, 42, 56, 84, and 112 .

Feed samples were taken from every other bag $(22.7$ $\mathrm{kg}$ ) of MR or starter and every bale of hay and composited by trial (nursery or grower). Composites of feeds were analyzed (AOAC International, 2000) for DM (oven method 930.15), ash (oven method 942.05), CP (Kjeldahl method 988.05), fat (alkaline treatment with Röse-Gottlieb method 932.06 for MR; diethyl ether extraction method 2003.05 for starters and hay), $\mathrm{Ca}$ and $\mathrm{P}$ (dry ashing, acid digestion, and analysis by inductively coupled plasma, method 985.01), NDF with ash without sodium sulfite or $\alpha$-amylase (Van Soest et al., 1991), ADF with ash (Robertson and Van Soest, 1981), starch ( $\alpha$-amylase method; Hall, 2009), and sugar (colorimetric method; Dubois et al., 1956). Geometric mean particle size distribution (ASAE, 1983) was measured using dry (chopped hay) and wet (starters) sieving methods (Shaver et al., 1988) using a vibratory sieve shaker.

In the nursery trial, data were analyzed as a randomized complete block design with a $2 \times 2 \times 2$ factorial arrangement of treatments and repeated measures by the MIXED procedure in SAS (version 8, SAS Institute Inc., Cary, NC). Calf (1 calf/pen) was the experimental unit. In the grower trial, data were analyzed as a randomized complete block design with a $2 \times 2$ factorial arrangement of treatments and repeated measures. Pen was the experimental unit. When there were interactions of main effects, treatment means were separated using a protected LSD test. An auto-regressive type 1 covariance matrix was employed as determined using Akaike's information criterion. Block of calves was considered random in all models. Significance was determined at $P \leq 0.05$ and statistical trends were determined at $0.10>P>0.05$.

Table 1. Ingredient composition and nutrient analyses of 2 milk replacers

\begin{tabular}{|c|c|c|}
\hline Item & $\begin{array}{c}\text { No } \\
\text { yolk }\end{array}$ & $\begin{array}{l}\text { High } \\
\text { yolk }\end{array}$ \\
\hline \multicolumn{3}{|l|}{ Ingredient, $\%$ as-fed } \\
\hline Whey & 49.83 & 52.41 \\
\hline Dry fat, $7 \% \mathrm{CP}, 60 \%$ fat & 22.71 & 13.64 \\
\hline Whey protein concentrate, $80 \% \mathrm{CP}$ & 22.67 & 19.28 \\
\hline Emulsifier blend ${ }^{1}$ & 1.65 & 1.65 \\
\hline NeoTec5G premix ${ }^{2}$ & 1 & 1 \\
\hline Dicalcium phosphate $18.5 \% \mathrm{P}$ & 0.38 & - \\
\hline DL-Methionine & 0.36 & 0.33 \\
\hline Calcium carbonate & 0.3 & 0.54 \\
\hline Flavor & 0.3 & 0.3 \\
\hline L-Lysine & 0.29 & 0.34 \\
\hline Flow agent & 0.2 & 0.2 \\
\hline Vitamin, trace mineral premix ${ }^{1}$ & 0.17 & 0.17 \\
\hline Choline chloride & 0.1 & 0.1 \\
\hline Bovatec $150 \mathrm{FP}^{3}$ & 0.03 & 0.03 \\
\hline Clarifly $8 \%^{4}$ & 0.01 & 0.01 \\
\hline Dried egg yolk ${ }^{5}$ & - & 10 \\
\hline \multicolumn{3}{|l|}{ Analyzed nutrient, $\%$ as-fed } \\
\hline $\mathrm{DM}$ & 95.4 & 95.5 \\
\hline \multicolumn{3}{|l|}{ Analyzed nutrient, \% of DM } \\
\hline $\mathrm{CP}$ & 27.1 & 27.8 \\
\hline Sugar & 16.6 & 16.4 \\
\hline Starch & 6.4 & 7 \\
\hline Fat & 19 & 20.1 \\
\hline Ash & 7 & 6.9 \\
\hline $\mathrm{Ca}$ & 0.79 & 0.76 \\
\hline $\mathrm{P}$ & 0.66 & 0.66 \\
\hline Digestible energy, ${ }^{6} \mathrm{Mcal} / \mathrm{kg}$ & 5 & 5.1 \\
\hline $\mathrm{ME},{ }^{6} \mathrm{Mcal} / \mathrm{kg}$ & 4.8 & 4.9 \\
\hline
\end{tabular}

${ }^{1}$ Provimi North America, Brookville, OH.

${ }^{2}$ Blend of fatty acids and nutrients, Provimi North America.

${ }^{3}$ Zoetis, Florham Park, NJ.

${ }^{4}$ Wellmark International, West Schaumberg, IL.

${ }^{5} 30 \%$ CP, 56\% fat, Ballas Egg Products Corp., Zanesville, OH.

${ }^{6}$ Calculated using NRC (2001) equations. 
Table 2. Ingredient composition and nutrient analyses of starters and hay fed to calves from 0 to $112 \mathrm{~d}$ of age

\begin{tabular}{|c|c|c|c|c|c|}
\hline Item & $\begin{array}{l}\text { Low starch } \\
\text { Nursery }\end{array}$ & $\begin{array}{l}\text { Low starch } \\
\text { Grower }\end{array}$ & $\begin{array}{l}\text { High starch } \\
\text { Nursery }\end{array}$ & $\begin{array}{l}\text { High starch } \\
\text { Grower }\end{array}$ & $\begin{array}{c}\text { Grass hay } \\
\text { Grower }\end{array}$ \\
\hline \multicolumn{6}{|l|}{ Ingredient, $\%$ as fed } \\
\hline Soybean hulls & 41.32 & 41.32 & - & - & - \\
\hline Soybean meal & 17.99 & 17.99 & 23.91 & 23.91 & - \\
\hline Maltodextrin & 2.5 & 2.5 & 0.7 & 0.7 & - \\
\hline Molasses & 2.5 & 2.5 & $3.00^{1}$ & $3.00^{1}$ & - \\
\hline Salt & 0.6 & 0.6 & 0.6 & 0.6 & - \\
\hline Ameri-Bond $2 x^{3}$ & 0.5 & 0.5 & - & - & - \\
\hline Calcium carbonate & 0.44 & 0.44 & 1.27 & 1.27 & - \\
\hline Monocalcium phosphate & 0.33 & 0.33 & 0.78 & 0.78 & - \\
\hline Clarifly $0.67 \%^{4}$ & 0.07 & 0.07 & 0.07 & 0.07 & - \\
\hline Corn, whole & - & - & $37.00^{1}$ & $37.00^{1}$ & - \\
\hline Oats, whole & - & - & $25.00^{1}$ & $25.00^{1}$ & - \\
\hline \multicolumn{6}{|l|}{ Analyzed nutrient, $\%$ as fed } \\
\hline $\mathrm{DM}$ & 88.7 & 88.5 & 87.4 & 87.6 & 87.1 \\
\hline \multicolumn{6}{|l|}{ Analyzed nutrient, \% DM } \\
\hline $\mathrm{CP}$ & 22.2 & 22.3 & 20.2 & 19.9 & 10.8 \\
\hline $\mathrm{ADF}$ & 24.6 & 24.2 & 8 & 8.1 & 40.6 \\
\hline NDF & 41.8 & 41.5 & 17.1 & 17.2 & 60 \\
\hline Sugar & 5.5 & 5.6 & 6.4 & 6.5 & 7.2 \\
\hline Starch & 10.1 & 10.3 & 43.1 & 43.5 & 3.8 \\
\hline Fat & 3.9 & 3.8 & 3.3 & 3.4 & 2.4 \\
\hline Ash & 9 & 8.9 & 6.9 & 6.8 & 8.3 \\
\hline $\mathrm{Ca}$ & 0.94 & 0.93 & 1 & 1.02 & 0.66 \\
\hline $\mathrm{P}$ & 0.58 & 0.57 & 0.69 & 0.68 & 0.24 \\
\hline Digestible energy, ${ }^{7} \mathrm{Mcal} / \mathrm{kg}$ & 3.3 & 3.3 & 3.6 & 3.6 & 2.6 \\
\hline $\mathrm{ME},{ }^{7} \mathrm{Mcal} / \mathrm{kg}$ & 2.6 & 2.6 & 2.7 & 2.7 & 2.1 \\
\hline Mean particle size, ${ }^{8} \mu \mathrm{m}$ & 824 & 849 & 2,105 & 2,187 & 2,536 \\
\hline
\end{tabular}

${ }^{1}$ These ingredients were not within the pellet that contained the other ingredients.

${ }^{2}$ Premix with vitamins, trace minerals, fatty acids, and nutrients (Provimi North America, Brookville, $\mathrm{OH}$ ).

${ }^{3}$ Pellet binder, Borregaard LignoTech, Sarpsborg, Norway.

${ }^{4}$ Wellmark International, West Schaumberg, IL.

${ }^{5}$ Blended by Provimi North America from Bovatec 91.

${ }^{6}$ Zoetis, Florham Park, NJ.

${ }^{7}$ Calculated using NRC (2001) equations.

${ }^{8}$ Geometric mean particle size (ASAE, 1983).

\section{RESULTS}

During the 0- to 56-d nursery trial, main effect and week interactions were observed $(P<0.001)$ for calf starter intake and BW gain, with a tendency $(P<$ $0.09)$ for an interaction for hip width change (Figure 1). Initial calf measurements did not differ $(P>0.05)$ for any main effect (Table 3 ). Calves fed $0 \%$ yolk MR had greater $(P<0.05)$ ADG, starter intake, feed efficiency, hip width change, and BCS change and lower $(P<$ $0.05)$ fecal scores than calves fed $10 \%$ yolk MR. Calves fed the high MR rate had greater $(P<0.05)$ ADG, feed efficiency, hip width change, BCS change, fecal scores, abnormal fecal score days, and medical treatment days and lower starter intake than calves fed the low MR rate. Calves fed high-starch starter had greater $(P<0.05)$ ADG, starter intake, hip width change, BCS change, and fecal scores and lower medical treatment days than calves fed the low-starch starter.

During the 56- to 112-d grower trial, calf performance changed $(P<0.05)$ depending on 28 -d phase (Table 4$)$. From d 56 to 84, calves previously fed the high MR rate with low starch or the low MR rate with high starch had the greatest ADG and feed efficiency, but from d 84 to 112 calves previously fed the high MR rate and low starch had the lowest ADG and were the least feed efficient. Treatment means are shown in Table 5, and main effect means are shown in Table 6. Calves fed the low-MR, high-starch treatment had the greatest $(P$ $<0.05)$ ADG and change in hip width of the 4 treat- 
a) Starter intake; $\mathrm{SEM}=0.0653 \mathrm{~kg} / \mathrm{d}, P<0.001$ for week by treatment interaction.

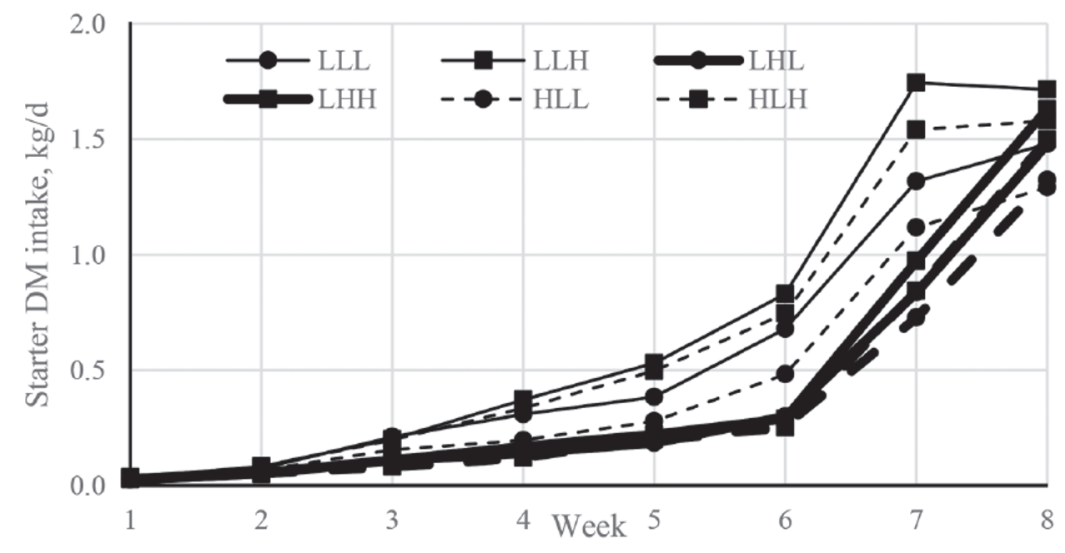

b) Accumulating BW gain; $\mathrm{SEM}=3.3 \mathrm{~kg}, P<0.001$ for week by treatment interaction.

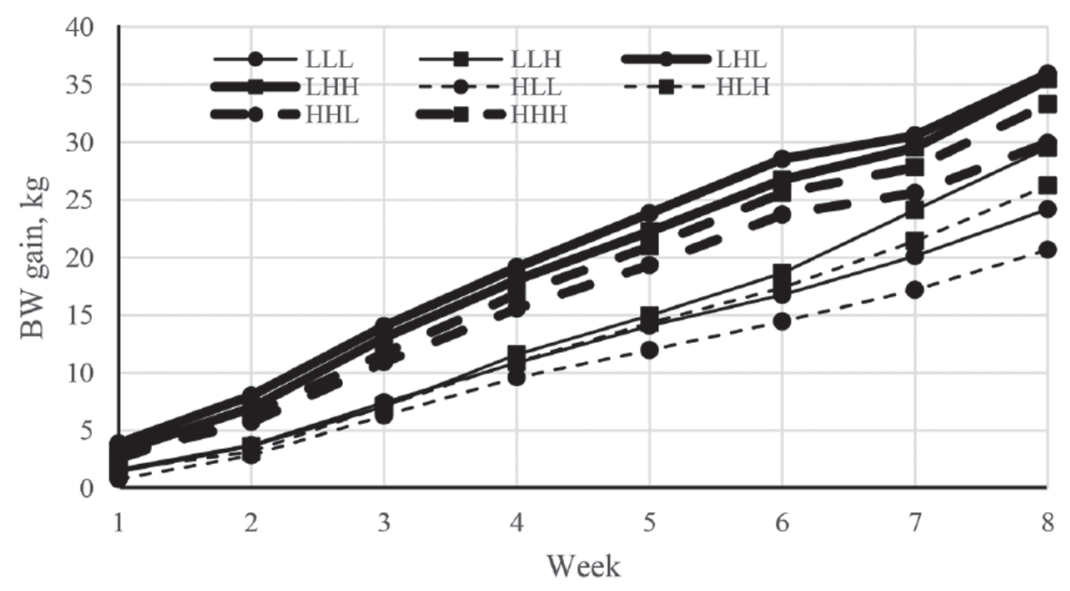

c) Accumulating hip width change; $\mathrm{SEM}=0.068 \mathrm{~cm}, P<0.09$ for week by treatment interaction.

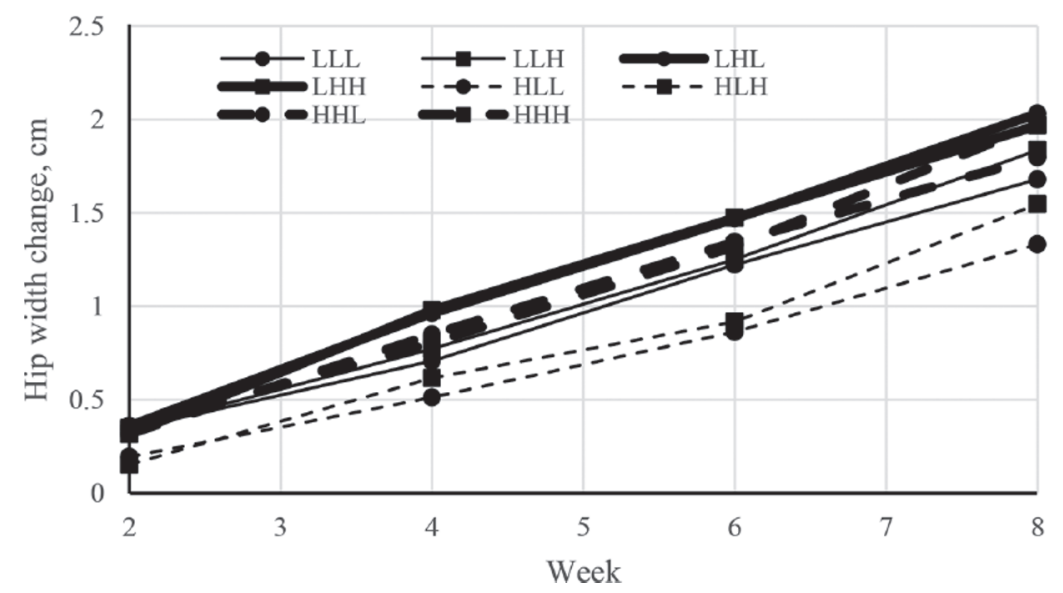

Figure 1. Starter intake (a), accumulating BW gain (b), and accumulating hip width change (c) of calves fed 6 feeding programs (n $=24$ calves) by week over the nursery trial. In the 3-letter combination, the first letter represents low (L) or high $(\mathrm{H})$ yolk concentration, the second letter represents milk replacer rate $(\mathrm{L}$ or $\mathrm{H})$, and the third letter represents starter starch concentration $(\mathrm{L}$ or $\mathrm{H})$. Low (solid line) was $0 \%$ dried egg yolk in the milk replacers, whereas high (broken line) was 10\%. The low milk replacer rate (thin line) was $0.66 \mathrm{~kg}$ of DM fed in 2 equal meals for $39 \mathrm{~d}$ followed by $0.33 \mathrm{~kg}$ of DM fed in the $0100 \mathrm{~h}$ meal for $3 \mathrm{~d}$. The high rate (thick line) was $0.87 \mathrm{~kg}$ of DM fed in 2 equal meals twice daily for $5 \mathrm{~d}$, followed by $1.08 \mathrm{~kg}$ of DM fed in 2 equal meals twice daily for $37 \mathrm{~d}$, followed by $0.43 \mathrm{~kg}$ of DM fed in the $0100 \mathrm{~h}$ meal for $7 \mathrm{~d}$. Starters contained either $10 \%$ starch (circle) or $43 \%$ starch (square). (a) Starter intake; SEM $=0.0653 \mathrm{~kg} / \mathrm{d}, P<0.001$ for week by treatment interaction. (b) Accumulating BW gain; SEM $=3.3 \mathrm{~kg}, P<0.001$ for week by treatment interaction. (c) Accumulating hip width change; SEM $=0.068 \mathrm{~cm}$, $P<0.09$ for week by treatment interaction. 
DENNIS ET AL.

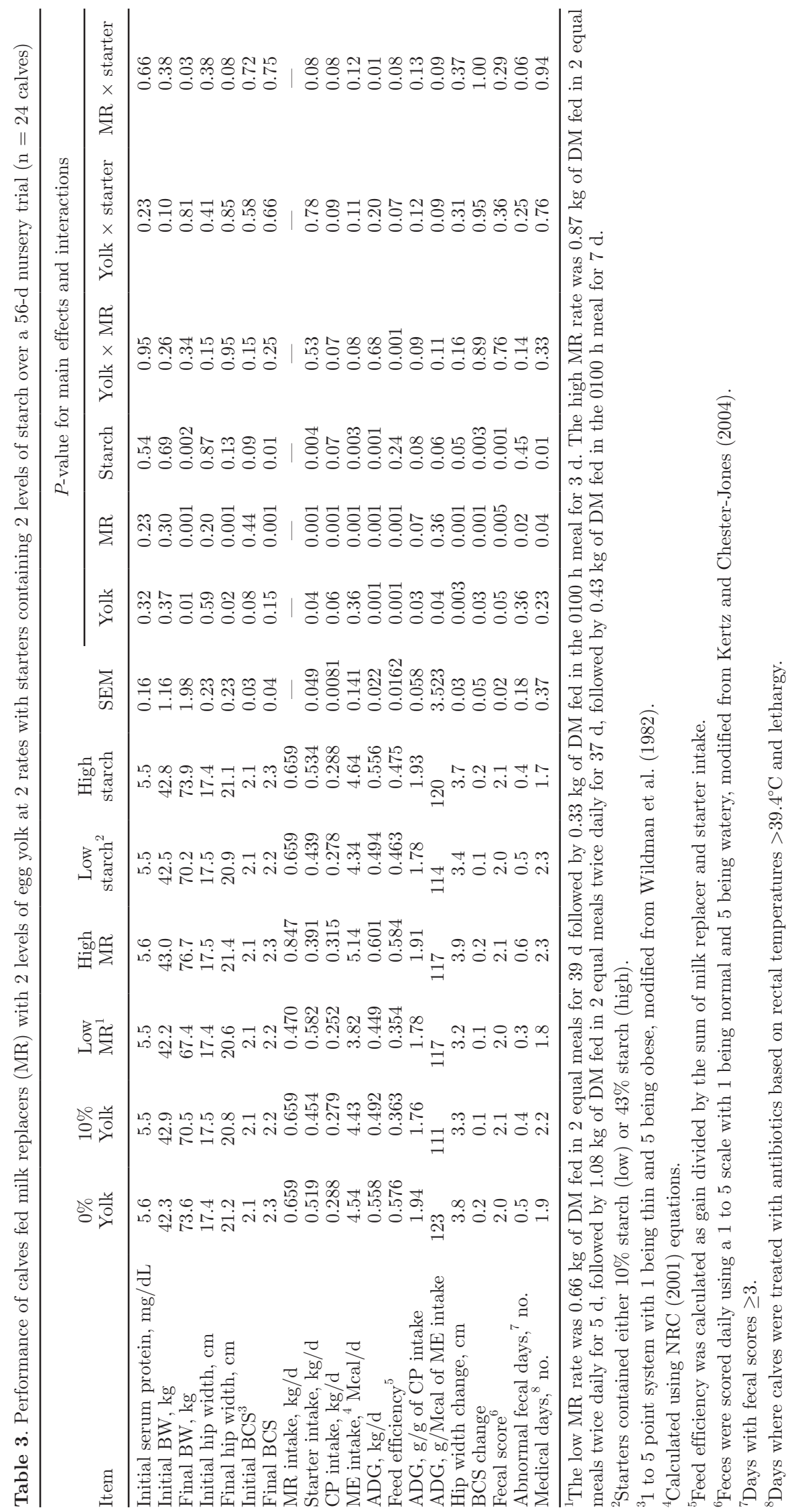


ments. Ending BW were greatest $(P<0.05)$ for calves fed the high-starch treatments, intermediate $(P<0.05)$ for calves fed the high-MR, low-starch treatment, and least $(P<0.05)$ for calves fed the low-MR, low-starch treatment. Ending hip widths were least $(P<0.05)$ for calves fed the low-MR, low-starch treatments versus the other treatments. For main effects, calves fed the low MR rate had greater $(P<0.05)$ hip width change than calves fed the high MR rate. Calves fed highstarch starter had greater $(P<0.05)$ ADG, hip width change, BCS change, and feed efficiency than calves fed low-starch starter.

Over the $112 \mathrm{~d}$, experimental units changed from calf in the nursery trial to pen in grower trial, so statistics could not be used to compare total intake and growth. Over the $112 \mathrm{~d}$, MR intake was $26 \mathrm{~kg}$ and starter intake $166 \mathrm{~kg}$ for a total DMI of $192 \mathrm{~kg}$ for calves fed the low $\mathrm{MR}$ rate. These calves gained $7.9 \mathrm{~cm}$ of hip width and $80 \mathrm{~kg}$ of BW with a feed efficiency of $0.42 \mathrm{~kg}$ of BW gain/kg of total DMI (G:F). Over the $112 \mathrm{~d}$, MR intake was $42 \mathrm{~kg}$ and starter intake $165 \mathrm{~kg}$ for a total DMI of $213 \mathrm{~kg}$ for calves fed the high MR rate. These calves gained $8.2 \mathrm{~cm}$ of hip width and $87 \mathrm{~kg}$ of BW with a feed efficiency of $0.41 \mathrm{G}: \mathrm{F}$. Whereas BW gain appeared to favor calves fed more MR, hip width change and feed efficiency were numerically similar.

When making similar comparisons of calves fed the low- and high-starch starters over the $112 \mathrm{~d}$, MR intake was the same $(37 \mathrm{~kg})$ and starter intake was appeared numerically greater for calves fed high starch (173 vs. $159 \mathrm{~kg}$ ). Calves fed the low-starch starter gained $7.4 \mathrm{~cm}$ hip width, $77 \mathrm{~kg}$ of BW, and had a feed efficiency of 0.39 G:F. Calves fed the high-starch starter gained 8.7 cm hip width, $91 \mathrm{~kg}$ of BW, and had a feed efficiency of $0.43 \mathrm{G}: \mathrm{F}$, appearing to perform better than calves fed the low-starch starter.

\section{DISCUSSION}

Diets with $10 \%$ egg yolk were inferior to diets without egg yolk with respect to any growth measurement in the current study. Quigley (2002) reported inclusion of 10 and $20 \%$ SDWE in a $24 \% \mathrm{CP}, 22 \%$ fat (DM basis) MR did not support the same ADG as MR without egg when fed at increasing and decreasing amounts from 0 to $6 \mathrm{wk}$ of age to average $0.53 \mathrm{~kg}$ of $\mathrm{MR} \mathrm{DM} / \mathrm{d}$. Touchette et al. (2003) reported 5\% SDWE in a $21 \%$ CP, $19 \%$ fat (DM basis) MR could support the ADG of a conventional MR without egg when fed at $0.44 \mathrm{~kg}$ of MR DM/d from 0 to 6 wk of age. However, when fed conventional MR with 10 or $20 \%$ SDWE, ADG declined compared with MR without egg. Little is understood regarding why negative effects of including egg prod-

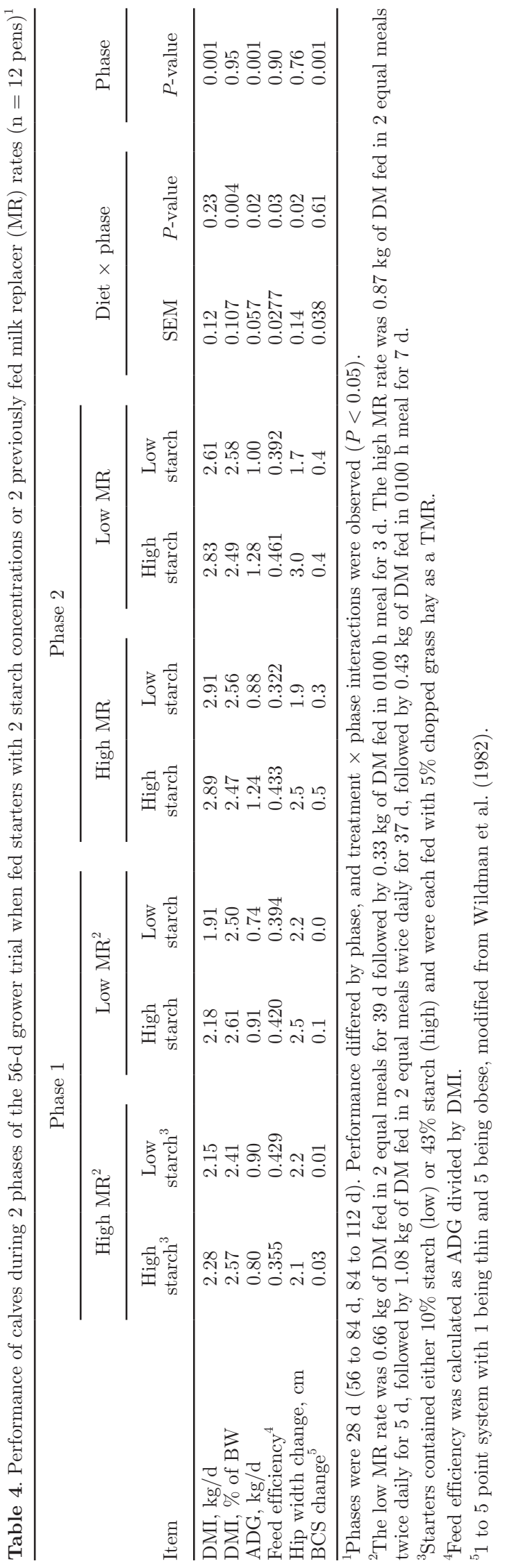

Journal of Dairy Science Vol. 100 No. 11, 2017 
Table 5. Treatment means for performance of calves from 56 to $112 \mathrm{~d}$ (grower trial) when fed starters with 2 starch concentrations or 2 previously fed milk replacer rates $(\mathrm{n}=12 \text { pens })^{1}$

\begin{tabular}{lcccccc}
\hline & \multicolumn{2}{c}{${\text { High } \mathrm{MR}^{2}}$} & & \multicolumn{2}{c}{ Low MR $^{2}$} & \\
\cline { 2 - 3 } \cline { 5 - 7 } Item & $\begin{array}{c}\text { High } \\
\text { starch }^{3}\end{array}$ & $\begin{array}{c}\text { Low } \\
\text { starch }^{3}\end{array}$ & & $\begin{array}{c}\text { High } \\
\text { starch }\end{array}$ & $\begin{array}{c}\text { Low } \\
\text { starch }\end{array}$ & SEM \\
\hline Initial BW, kg & 77.5 & 76.0 & & 70.3 & 66.2 & 1.646 \\
Final BW, kg & $134.7^{\mathrm{c}}$ & $125.8^{\mathrm{b}}$ & & $131.4^{\mathrm{c}}$ & $114.7^{\mathrm{a}}$ & \\
Initial hip width, cm & 21.4 & 21.4 & & 20.7 & 20.5 & 0.185 \\
Final hip width, cm & $26.0^{\mathrm{b}}$ & $25.5^{\mathrm{b}}$ & & $26.2^{\mathrm{b}}$ & $24.4^{\mathrm{a}}$ & 0.207 \\
Initial BCS & 2.4 & 2.3 & & 2.2 & 2.2 & 0.032 \\
Final BCS & 2.9 & 2.6 & & 2.8 & 2.6 & 0.076 \\
DMI, kg/d & 2.59 & 2.53 & & 2.5 & 2.26 & 0.117 \\
DMI, \% of BW & 2.52 & 2.48 & & 2.55 & 2.54 & 0.103 \\
ADG, kg/d & $1.02^{\mathrm{b}}$ & $0.89^{\mathrm{a}}$ & & $1.09^{\mathrm{c}}$ & $0.87^{\mathrm{a}}$ & 0.019 \\
Feed efficiency & 0.394 & 0.375 & & 0.440 & 0.393 & 0.0173 \\
Hip width change, cm & $4.6^{\mathrm{c}}$ & $4.1^{\mathrm{b}}$ & & $5.4^{\mathrm{d}}$ & $3.9^{\mathrm{a}}$ & 0.11 \\
BCS change & 0.5 & 0.3 & & 0.6 & 0.4 & 0.05 \\
\hline
\end{tabular}

${ }^{\mathrm{a}-\mathrm{d}}$ Means within a row with different superscripts differ $(P<0.05)$.

${ }^{1}$ Phases were 28 d ( 56 to 84 d, 84 to 112 d). Performance differed by 28 -d phase, and treatment $\times$ phase interactions were observed $(P<0.05)$ as shown in Table 4 . When main effects interacted $(P<0.05)$, treatment means were separated with a protected LSD test.

${ }^{2}$ The low milk replacer rate (MR) was $0.66 \mathrm{~kg}$ of DM fed in 2 equal meals for $39 \mathrm{~d}$ followed by $0.33 \mathrm{~kg}$ of DM fed in $0100 \mathrm{~h}$ meal for $3 \mathrm{~d}$. The high rate was $0.87 \mathrm{~kg}$ of DM fed in 2 equal meals twice daily for $5 \mathrm{~d}$, followed by $1.08 \mathrm{~kg}$ of DM fed in 2 equal meals twice daily for $37 \mathrm{~d}$, followed by $0.43 \mathrm{~kg}$ of DM fed in $0100 \mathrm{~h}$ meal for $7 \mathrm{~d}$.

${ }^{3}$ Starters contained either $10 \%$ starch (low) or $43 \%$ starch (high) and were each fed with $5 \%$ chopped grass hay as a TMR.

${ }^{4} 1$ to 5 point system with 1 being thin and 5 being obese, modified from Wildman et al. (1982).

${ }^{5}$ Feed efficiency was calculated as ADG divided by DMI.

Table 6. Main effect means for performance of calves from 56 to $112 \mathrm{~d}$ when fed starters with 2 starch concentrations or 2 previously fed milk replacer $(\mathrm{MR})$ rates $(\mathrm{n}=12 \text { pens })^{1}$

\begin{tabular}{|c|c|c|c|c|c|c|c|c|}
\hline Item & $\begin{array}{l}\text { Low } \\
\text { MR }^{2}\end{array}$ & $\begin{array}{l}\text { High } \\
\text { MR }\end{array}$ & $\begin{array}{c}\text { Low } \\
\text { starch }^{3}\end{array}$ & $\begin{array}{l}\text { High } \\
\text { starch }\end{array}$ & SEM & \multicolumn{3}{|c|}{$P$-value } \\
\hline Final BW, kg & 123.1 & 130.3 & 120.3 & 133.1 & 1.696 & 0.001 & 0.001 & 0.02 \\
\hline Initial hip width, $\mathrm{cm}$ & 20.6 & 21.4 & 21 & 21.1 & 0.185 & 0.001 & 0.67 & 0.56 \\
\hline Final hip width, cm & 25.3 & 25.8 & 25 & 26.1 & 0.207 & 0.021 & 0.001 & 0.002 \\
\hline Initial $\mathrm{BCS}^{4}$ & 2.2 & 2.3 & 2.2 & 2.3 & 0.032 & 0.001 & 0.001 & 0.53 \\
\hline Hip width change, $\mathrm{cm}$ & 4.7 & 4.3 & 4 & 5 & 0.11 & 0.001 & 0.001 & 0.001 \\
\hline BCS change & 0.5 & 0.4 & 0.4 & 0.5 & 0.05 & 0.24 & 0.003 & 0.99 \\
\hline DMI, $\mathrm{kg} / \mathrm{d}$ & 2.38 & 2.56 & 2.39 & 2.55 & 0.117 & 0.14 & 0.2 & 0.43 \\
\hline $\mathrm{CP}$ intake, $\mathrm{kg} / \mathrm{d}$ & 0.496 & 0.533 & 0.478 & 0.552 & 0.0202 & 0.06 & 0.05 & 0.39 \\
\hline ME intake, Mcal/d & 6.31 & 6.78 & 6.45 & 6.63 & 0.2598 & 0.06 & 0.11 & 0.42 \\
\hline DMI, $\%$ of BW & 2.55 & 2.5 & 2.51 & 2.54 & 0.103 & 0.67 & 0.81 & 0.92 \\
\hline Feed efficiency ${ }^{5}$ & 0.417 & 0.385 & 0.384 & 0.417 & 0.0173 & 0.07 & 0.07 & 0.42 \\
\hline
\end{tabular}

${ }^{1}$ Phases were $28 \mathrm{~d}$ (56 to $84 \mathrm{~d}, 84$ to $\left.112 \mathrm{~d}\right)$. Performance differed by 28 -d phase, and treatment $\times$ phase interactions were observed $(P<0.05)$ as shown in Table 4 . Treatment means are shown in Table 5.

${ }^{2}$ The low milk replacer rate (MR) was $0.66 \mathrm{~kg}$ of DM fed in 2 equal meals for $39 \mathrm{~d}$ followed by $0.33 \mathrm{~kg}$ of DM fed in $0100 \mathrm{~h}$ meal for $3 \mathrm{~d}$. The high rate was $0.87 \mathrm{~kg}$ of DM fed in 2 equal meals twice daily for $5 \mathrm{~d}$, followed by $1.08 \mathrm{~kg}$ of DM fed in 2 equal meals twice daily for $37 \mathrm{~d}$, followed by $0.43 \mathrm{~kg}$ of $\mathrm{DM}$ fed in $0100 \mathrm{~h}$ meal for $7 \mathrm{~d}$.

${ }^{3}$ Starters contained either $10 \%$ starch (low) or $43 \%$ starch (high) and were each fed with $5 \%$ chopped grass hay as a TMR.

${ }^{4} 1$ to 5 point system with 1 being thin and 5 being obese, modified from Wildman et al. (1982).

${ }^{5}$ Feed efficiency was calculated as ADG divided by DMI. 
ucts in calf MR are observed. One of the predominant phospholipids in egg yolk is phosvitin, which potently sequesters $\mathrm{Ca}$ and other divalent cations due to the high phosphorylation of the molecule (Samaraweera et al., 2011). Ishikawa et al. (2007) reported including egg yolk protein at $20 \%$ of the diet for rats reduced protein (95.6 vs. $93.0 \%), \mathrm{Ca}(74.8$ vs. $63.3 \%), \mathrm{Mg}$ (73.1 vs. $61.4 \%$ ), and $\mathrm{P}$ (90.7 vs. $72.9 \%$ ) digestibility compared with feeding casein at the same rate. It is possible that MR digestibility was reduced when egg yolk was included at $10 \%$ of the formula; however, we are not aware of digestibility data for calves when fed SDWE or egg yolk proteins. Our current research with 10\% egg yolk agrees with prior research reporting that SDWE at $\geq 10 \%$ of the MR was inferior to MR based on all-milk proteins.

In the current study, feeding high versus low rates of MR increased ADG, feed efficiency, hip width change, and BCS change in the first 2 mo; however, feeding calves low versus high rates of $\mathrm{MR}$ increased hip width from 2 to 4 mo of age. This pattern of BW and structural growth with high and low rates of MR is commonly reported where postweaning periods of approximately 2 mo were studied and many reported no difference in BW and structural growth measurements at the end of their postweaning periods between different amounts of milk or MR fed to calves (Nocek and Braund, 1986; Bar-Peled et al., 1997; Hill et al., 2007, 2010, 2013). Some have also reported increases in BW but not structural measurements at the end of the postweaning measurements. Osorio et al. (2012) reported $4 \%$ greater BW but no difference in hip widths at $20 \mathrm{wk}$ of age between high and low rates of MR. Morrison et al. (2009) reported $6.5 \mathrm{~kg}$ heavier BW at $90 \mathrm{~d}(15 \%$ more ADG) with high versus low MR but no difference in structural measurements after weaning (56 d of age). Kiezebrink et al. (2015) reported greater BW up to 52 wk of age and greater withers heights up to 16 wk of age in heifers fed high versus low MR rates; however, BW and withers heights were similar thereafter. Raeth-Knight et al. (2009) reported that preweaning ADG and hip height gain advantages from feeding high versus low rates of MR were maintained to 6 mo of age. They reported calves fed the high rate of MR having $8.8 \mathrm{~kg}$ heavier BW and being $1.8 \mathrm{~cm}$ taller at the hips than calves fed a low rate of MR and $6.7 \mathrm{~kg}$ heavier BW and $1.1 \mathrm{~cm}$ taller at the hips than calves fed an intermediate rate of MR at 6 mo of age. In the current trial, final BW and hip widths for the main of effect of MR feeding rate were $7.2 \mathrm{~kg}$ and $0.5 \mathrm{~cm}$ more, respectively, for calves fed high versus low MR rates. Change in BW and hip width over 4 mo was 7.4 $\mathrm{kg}(+9 \%)$ and $0.3 \mathrm{~cm}(+4 \%)$ more for calves fed high versus low MR rates.
A concern when comparing milk and MR feeding rates is the potential effect of weaning age. An older weaning age should and can increase ADG of calves in the first 2 mo of life by allowing for more consumption of milk or MR that is high in energy and highly digestible relative to calf starter, especially when large amounts of milk or MR are fed (Eckert et al., 2015; Meale et al., 2015; Wood et al., 2015). The weaning process has been shown to increase gut permeability, an occurrence that is likely a stress to the calf's physiology (Meale et al., 2015). It is also unknown whether changes in gut permeability around weaning are repeatable in research or are affected by weaning age. It is known that calves fed a large amount of MR will have lower digestibility of starter postweaning than calves fed moderate amounts of MR (Hill et al., 2010, 2016b,c) and this difference in digestion appears to persist for at least $4 \mathrm{wk}$. This reduces postweaning growth of calves. However, much of the research comparing weaning age of calves fed large amounts of MR has only measured BW gain and not structural growth. Gain in BW is both gain in carcass and gain in gut tissue and gut fill, which are poor indicators of actual lean tissue growth immediately after weaning. The use of only BW to measure growth is especially concerning with large MR feeding programs when starter intake increases rapidly from amounts of 100 to $200 \mathrm{~g} / \mathrm{d}$ up to more than $1 \mathrm{~kg} / \mathrm{d}$ within a week after weaning when digestion is compromised and low (Hill et al., 2010, 2016b; Rosenberger et al., 2017). Additionally, many comparisons are only made for 1 to 3 wk postweaning (Eckert et al., 2015; Wood et al., 2015; Rosenberger et al., 2017). When comparing the effect of weaning at 6 or 8 wk of age using a 7-d weaning strategy on calves fed up to $1.1 \mathrm{~kg} / \mathrm{d}$ of MR DM, structural growth postweaning did not differ; however, BW gain was greater for calves weaned at 8 wk up to 12 wk of age (Dennis et al., 2017a,b). Overall BW gain and $\mathrm{BW}$ at 16 wk of age were similar for calves weaned at 6 or 8 wk of age when fed up to $1.1 \mathrm{~kg} / \mathrm{d}$ of MR DM (Dennis et al., 2017a,b). Duration of weaning may alleviate some potential negative effects around weaning for calves fed high amounts of milk or MR. Abrupt weaning over $4 \mathrm{~d}$ reduced postweaning intake of starter, whereas gradual weaning over $10 \mathrm{~d}$ was suggested to be optimal in maximizing starter intake in programs with large amounts of MR were fed (Sweeney et al., 2010). A recent comparison of weaning over 7 or $14 \mathrm{~d}$ to complete weaning by $8 \mathrm{wk}$ of age reported greater OM digestibility at $12 \mathrm{wk}$ of age for calves weaned over $14 \mathrm{~d}$, but no statistical differences in BW or hip width gain to 16 wk of age between weaning treatments (Dennis et al., 2017a,b).

In the current study, during the first 2 mo of age, efficiency of DM use for ADG was greater for high versus 
low MR rates, similar to Osorio et al. (2012). Efficiency of $\mathrm{CP}$ use for ADG tended to be greater for high versus low MR rates; however, efficiency of ME use did not differ between MR rates. From 2 to 4 mo of age, the reverse was true, as calves fed the low rate of MR were more efficient than those fed the high rate of MR. Over the entire $4 \mathrm{mo}$, these efficiencies tended to be not different to slightly better for calves fed less versus more MR. It is counterintuitive for calves fed more of a highly digestible MR to have poorer feed efficiency than calves fed less MR. It appears that this difference is best explained by feeding more MR slowing rumen development during the preweaning period (Terré et al., 2007a,b; Suarez-Mena et al., 2011) and reducing the digestibility of the dry feeds (Terré et al., 2007a,b; Hill et al., 2010, 2016c; Chapman et al., 2016). This slowing of rumen development by feeding more MR is likely the reason why growth and efficiency measurements from 2 and 4 mo of age are less for calves fed more versus less MR. With starter intakes between calves fed the 2 MR rates being similar, if digestibility was less in calves fed high versus low MR rates, gut fill might be inflating BW and ADG in calves fed the high MR rate. This could explain the changes in ADG during wk 6, 7, and 8, shown in Figure 1. Calves fed more MR also had more medical treatments for respiratory sickness. Similarly, Hengst et al. (2012) reported more respiratory sickness for calves fed more versus less MR. Others have reported less immune function preweaning as indicated by less T-helper cell function (Foote et al., 2005, 2007), less leukocyte function (Nonnecke et al., 2003), and less L-selectin (Obeidat et al., 2013) when calves were fed more versus less MR.

Calves fed high-starch starters had greater ADG, starter intake, hip width change, and BCS change in both pre- and postweaning to 4 mo of age. This has been reported previously (Hill et al., 2008, 2012; Suarez-Mena et al., 2011; Terré et al., 2013) and supported by recent measurements in 2- to 4-mo-old calves where digestibility of high-starch starters was greater than low-starch starters (Hill et al., 2016c). In this report, we did not estimate gut fill or report empty BW gain, we only reported ADG. Gut fill and gut tissue has been greater in high-fiber diets fed to calves between birth and 20 wk of age (Jahn et al., 1970; Jahn and Chandler, 1976; Jahn et al., 1976; Fokkink et al., 2011; Khan et al., 2011) and this can inflate ADG estimates of high- versus low-fiber diets.

To summarize, $10 \%$ egg yolk in the MR reduced ADG, hip width change, and starter intake from 0 to $56 \mathrm{~d}$ by 11 to $13 \%$. Feeding the high MR rate increased ADG during the first $56 \mathrm{~d}$ of age, but resulted in lesser hip width change from 56 to $112 \mathrm{~d}$ of age compared with the low MR feeding rate. High MR feeding rates reduced starter intake in the first $56 \mathrm{~d}$ compared with the low MR feeding rate. Low-starch pelleted starters were consumed in lesser amounts during the first $56 \mathrm{~d}$ compared with high-starch texturized starters. Calves fed high-starch starters had the greatest ending BW and hip widths. In this trial, the high-starch starter program was more important to calf performance over the initial 4 mo of a calf's life than the high MR rate program.

\section{CONCLUSIONS}

Feeding the MR with dried egg yolk reduced calf growth. Feeding the MR up to $1.08 \mathrm{~kg}$ of $\mathrm{DM} / \mathrm{d}$ improved growth in the first $56 \mathrm{~d}$ but reduced growth in the next $56 \mathrm{~d}$ compared with feeding $0.66 \mathrm{~kg}$ of $\mathrm{DM} / \mathrm{d}$. Feeding the $43 \%$ starch texturized starter improved growth in the first and second 56-d periods compared with the $10 \%$ starch pelleted starter. Growth (BW and structural growth) over the first $112 \mathrm{~d}$ of calf life was over 2-fold greater from feeding the high- versus lowstarch starter than feeding the high versus low MR rate.

\section{ACKNOWLEDGMENTS}

This research was fully funded by Provimi, Brookville, Ohio.

\section{REFERENCES}

AOAC International. 2000. Official Methods of Analysis. Vol. I. 17th ed. AOAC International, Arlington, VA.

ASAE. 1983. Method of determining and expressing fineness of feed materials by sieving. Page 325 in ASAE Standard S319, Agriculture Engineers Yearbook of Standards. Am. Soc. Agric. Eng., St. Joseph, MI.

Bach, A. 2012. Nourishing and managing the dam and postnatal calf for optimal lactation, reproduction, and immunity. J. Anim. Sci. 90:1835-1845.

Bach, A., and J. Ahedo. 2008. Record keeping and economics of dairy heifers. Vet. Clin. North Am. Food Anim. Pract. 24:117-138.

Bar-Peled, U., B. Robinzon, E. Maltz, H. Tagari, Y. Folman, I. Bruckental, H. Voet, H. Gacitua, and A. R. Lehrer. 1997. Increased weight gain and effects on production parameters of Holstein heifer calves that were allowed to suckle from birth to six weeks of age. J. Dairy Sci. 80:2523-2528.

Byrne, B. M., M. Gruber, and G. Ab. 1989. The evolution of egg yolk proteins. Prog. Biophys. Mol. Biol. 53:33-69.

Chapman, C. E., P. S. Erickson, J. D. Quigley, T. M. Hill, H. G. Bateman II, F. X. Suarez-Mena, and R. L. Schlotterbeck. 2016. Effect of milk replacer program on calf performance and digestion of nutrients with age of the dairy calf. J. Dairy Sci. 99:2740-2747.

Davis, C. L., and J. K. Drackley. 1998. The Development, Nutrition, and Management of the Young Calf. Iowa State University Press, Ames.

Dennis, T. S., F. X. Suarez-Mena, T. M. Hill, J. D. Quigley, W. Hu, and R. L. Schlotterbeck. 2017a. Effects of milk replacer feeding rate and age at weaning on calf performance and digestion through 8 weeks of age. J. Dairy Sci. 100 (E-Suppl. 2):301. (Abstr.)

Dennis, T. S., F. X. Suarez-Mena, T. M. Hill, J. D. Quigley, W. Hu, and R. L. Schlotterbeck. 2017b. Effects of previous milk replac- 
er feeding program on calf performance and digestion through 4 months of age. J. Dairy Sci. 100 (E-Suppl. 2):301. (Abstr.)

Dubois, M., K. A. Gilles, J. K. Hamilton, P. A. Rebers, and F. Smith. 1956. Colorimetric method for determination of sugars and related substances. Anal. Chem. 28:350-356.

Eckert, E., H. E. Brown, K. E. Leslie, T. J. DeVries, and M. A. Steele. 2015. Weaning age affects growth, feed intake, gastrointestinal development, and behavior in Holstein calves fed an elevated plane of nutrition during the preweaning stage. J. Dairy Sci. 98:6315-6326.

FASS. 2010. Guide for the care and use of agricultural animals in agricultural research and teaching. 3rd ed. Federation of Animal Science Societies, Champaign, IL.

Fokkink, W. B., T. M. Hill, H. G. Bateman II, J. M. Aldrich, R. L. Schlotterbeck, and A. F. Kertz. 2011. Effect of high and low cereal grain starter on straw intake and rumen development of neonatal Holstein calves. Prof. Anim. Sci. 27:357-364.

Foote, M. R., B. J. Nonnecke, D. C. Beitz, and W. R. Waters. 2007. High growth rate fails to enhance adaptive immune responses of neonatal calves and is associated with reduced lymphocyte viability. J. Dairy Sci. 90:404-417.

Foote, M. R., B. J. Nonnecke, M. A. Fowler, B. L. Miller, D. C. Beitz, and W. R. Waters. 2005. Effects of age and nutrition on expression of CD25, CD44, and L-selectin (CD62L) on T-cells from neonatal calves. J. Dairy Sci. 88:2718-2729.

Gelsinger, S. L., A. J. Heinrichs, and C. M. Jones. 2016. A metaanalysis of the effects of preweaned calf nutrition and growth on first-lactation performance. J. Dairy Sci. 99:6206-6214.

Hall, M. B. 2009. Analysis of starch, including maltooligosaccharides, in animal feeds: A comparison of methods and a method recommended for AOAC collaborative study. J. AOAC Int. 92:42-49.

Heinrichs, A. J., and B. S. Heinrichs. 2011. A prospective study of calf factors affecting first-lactation and lifetime milk production and age of cows when removed from the herd. J. Dairy Sci. 94:336-341.

Hengst, B. A., L. M. Nemec, R. R. Rastani, and T. F. Gressley. 2012. Effect of conventional and intensified milk replacer feeding programs on performance, vaccination response, and neutrophil mRNA levels of Holstein calves. J. Dairy Sci. 95:5182-5193.

Hill, T. M., J. M. Aldrich, R. L. Schlotterbeck, and H. G. Bateman II. 2006a. Effects of feeding calves different rates and protein concentrations of twenty percent fat milk replacers on growth during the neonatal period. Prof. Anim. Sci. 22:252-260.

Hill, T. M., J. M. Aldrich, R. L. Schlotterbeck, and H. G. Bateman II. 2006b. Effects of feeding rate and concentrations of protein and fat of milk replacers fed to neonatal calves. Prof. Anim. Sci. $22: 374-381$.

Hill, T. M., J. M. Aldrich, R. L. Schlotterbeck, and H. G. Bateman II. 2007. Effects of the feeding rate of high protein calf milk replacers. Prof. Anim. Sci. 23:649-655.

Hill, T. M., H. G. Bateman, J. M. Aldrich, J. M. Quigley, and R. L. Schlotterbeck. 2013. Evaluation of acidified, ad libitum milk replacer programs for dairy calves. J. Dairy Sci. 96:3153-3162.

Hill, T. M., H. G. Bateman, J. M. Aldrich, and R. L. Schlotterbeck. 2008. Effects of feeding different carbohydrate sources and amounts to young calves. J. Dairy Sci. 91:3128-3137.

Hill, T. M., H. G. Bateman II, J. M. Aldrich, and R. L. Schlotterbeck. 2010. Effect of milk replacer program on digestion of nutrients in dairy calves. J. Dairy Sci. 93:1105-1115.

Hill, T. M., H. G. Bateman II, J. M. Aldrich, and R. L. Schlotterbeck. 2012. High-starch, coarse-grain, low-fiber diets maximize growth of weaned dairy calves less than 4 months of age. Prof. Anim. Sci. 28:325-331.

Hill, T. M., J. D. Quigley, H. G. Bateman II, J. M. Aldrich, and R. L. Schlotterbeck. 2016a. Source of carbohydrate and metabolizable lysine and methionine in the diet of recently weaned dairy calves on digestion and growth. J. Dairy Sci. 99:2788-2796.

Hill, T. M., J. D. Quigley, H. G. Bateman II, F. X. Suarez-Mena, T. S. Dennis, and R. L. Schlotterbeck. 2016b. Effect of milk replacer program on calf performance and digestion of nutrients in dairy calves to 4 months of age. J. Dairy Sci. 99:8103-8110.

Hill, T. M., J. D. Quigley, F. X. Suarez-Mena, H. G. Bateman II, and R. L. Schlotterbeck. 2016c. Effect of milk replacer feeding rate and functional fatty acids on dairy calf performance and digestion of nutrients. J. Dairy Sci. 99:6352-6361.

Ishikawa, S. I., S. Tamaki, K. Arihara, and M. Itoh. 2007. Egg yolk protein and egg yolk phosvitin inhibit calcium, magnesium, and iron absorptions in rats. J. Food Sci. 72:S412-S419.

Jahn, E., and P. T. Chandler. 1976. Performance and nutrient requirements of calves fed varying percentages of protein and fiber. J. Anim. Sci. 41:724-735.

Jahn, E., P. T. Chandler, and R. F. Kelly. 1976. Nutrient accumulation and prediction of body composition of 20 -week old calves fed varying percentages of protein and fiber. J. Anim. Sci. 42:737-744.

Jahn, E., P. T. Chandler, and C. E. Polan. 1970. Effects of fiber and ratio of starch to sugar on performance of ruminating calves. J. Dairy Sci. 53:466-474.

Kertz, A. F., and H. Chester-Jones. 2004. Invited Review: Guidelines for measuring and reporting calf and heifer experimental data. J. Dairy Sci. 87:3577-3580.

Khan, M. A., D. M. Weary, and M. A. G. von Keyserlingk. 2011. Hay intake improves performance and rumen development of calves fed higher quantities of milk. J. Dairy Sci. 94:3547-3553.

Kiezebrink, D. J., A. M. Edwards, T. C. Wright, J. P. Cant, and V. R. Osborne. 2015. Effect of enhanced whole-milk feeding in calves on subsequent first-lactation performance. J. Dairy Sci. 98:349-356.

Kosiorowska, A., L. Puggaard, M. S. Hedemann, J. Sehested, S. K. Jensen, N. B. Kristensen, P. Kuropka, K. Marycz, and M. Vestergaard. 2011. Gastrointestinal development of dairy calves fed low- or high-starch concentrate at two milk allowances. Animal 5:211-219.

Meale, S. J., L. N. Leal, J. Martín-Tereso, and M. A. Steele. 2015. Delayed weaning of Holstein bull calves fed an elevated plane of nutrition impacts feed intake, growth and potential markers of gastrointestinal development. Anim. Feed Sci. Technol. 209:268-273.

Morrison, S. J., H. C. F. Wicks, R. J. Fallon, J. Twigge, L. E. R Dawson, and A. R. G. Wylie. 2009. Effects of feeding level and protein content of milk replacer on the performance of dairy herd replacements. Animal 3:1570-1579.

Nocek, J. E., and D. G. Braund. 1986. Performance, health, and postweaning growth on calves fed cold, acidified milk replacer ad libitum. J. Dairy Sci. 69:1877-1883.

Nonnecke, B. J., M. R. Foote, J. M. Smith, B. A. Pesch, and M. E. Van Amburgh. 2003. Composition and functional capacity of blood mononuclear leukocyte populations from neonatal calves on standard and intensified milk replacer diets. J. Dairy Sci. 86:35923604 .

NRC. 2001. Nutrient Requirements of Dairy Cattle. 7th rev. ed. Natl. Acad. Sci., Washington, DC.

Obeidat, B. S., C. J. Cobb, M. D. Sellers, A. R. Pepper-Yowell, T. J. Earleywine, and M. A. Ballou. 2013. Plane of nutrition during the preweaning period but not the grower trial influences the neutrophil activity of Holstein calves. J. Dairy Sci. 96:7155-7166.

Osorio, J. S., R. L. Wallace, D. J. Tomlinson, T. J. Earleywine, M. T. Socha, and J. K. Drackley. 2012. Effects of source of trace minerals and plane of nutrition on growth and health of transported neonatal dairy calves. J. Dairy Sci. 95:5831-5844.

Quigley, J. D. III. 2002. Effects of spray-dried whole egg and biotin in calf milk replacer. J. Dairy Sci. 85:198-203.

Raeth-Knight, M., H. Chester-Jones, S. Hayes, J. Linn, R. Larson, D. Ziegler, B. Ziegler, and N. Broadwater. 2009. Impact of conventional or intensive milk replacer programs on Holstein heifer performance through six months of age and during first lactation. J. Dairy Sci. 92:799-809.

Robertson, J. B., and P. J. Van Soest. 1981. The Detergent System of Analysis and its Application to Human Foods. Cornell University, Ithaca, NY

Rosenberger, K., J. H. C. Costa, H. W. Neave, M. A. G. von Keyserlingk, and D. M. Weary. 2017. The effect of milk allowance on behavior and weight gains in dairy calves. J. Dairy Sci. 100:504-512.

Samaraweera, H., W. G. Zhang, E. J. Lee, and D. U. Ahn. 2011. Egg yolk phosvitin and functional phosphopeptides-Review. J. Food Sci. 76:R143-R150. 
Schaafsma, G. 2000. The protein digestibility-corrected amino acid score. J. Nutr. 130:1865S-1867S.

Shaver, R. D., A. J. Nytes, L. D. Satter, and N. A. Jorgensen. 1988. Influence of feed intake, forage physical form, and forage fiber content on particle size of masticated forage, ruminal digesta, and feces of dairy cattle. J. Dairy Sci. 71:1566-1572.

Soberon, F., E. Raffrenato, R. W. Everett, and M. E. Van Amburgh 2012. Preweaning milk replacer intake and effects on long-term productivity of dairy calves. J. Dairy Sci. 95:783-793.

Suarez-Mena, F. X., T. M. Hill, A. J. Heinrichs, H. G. Bateman II, J. M. Aldrich, and R. L. Schlotterbeck. 2011. Effects of including corn distillers dried grains with solubles in dairy calf feeds. J. Dairy Sci. 94:3037-3044.

Sweeney, B. C., J. Rushen, D. M. Weary, and A. M. de Passillé. 2010 Duration of weaning, starter intake, and weight gain of dairy calves fed large amounts of milk. J. Dairy Sci. 93:148-152.

Terré, M., M. Devant, and A. Bach. 2007a. Effect of level of milk replacer fed to Holstein calves on performance during the preweaning period and starter digestibility at weaning. Livest. Sci. 110:82-88.

Terré, M., M. Devant, and A. Bach. 2007b. Performance and nitrogen metabolism of calves fed conventionally or following an enhancedgrowth feeding program during the preweaning period. Livest. Sci. 105:109-119.
Terré, M., M. E. Pedrals, A. Dalmau, and A. Bach. 2013. What do preweaned and weaned calves need in the diet: A high fiber content or a forage source? J. Dairy Sci. 96:5217-5225.

Touchette, K. J., M. L. O'Brien, and J. A. Coalson. 2003. Liquid egg as an alternative protein source in calf milk replacers. J. Dairy Sci. 86:2622-2628

USDA. 2015. USDA Nutrient Database for Standard Reference, Release 28. Version Current: September 2015, slightly revised May 2016. https://www.ars.usda.gov/northeast-area/beltsville-md/beltsville -human-nutrition-research-center/nutrient-data-laboratory/docs/ usda-national-nutrient-database-for-standard-reference/.

Van Soest, P. J., J. B. Robertson, and B. A. Lewis. 1991. Methods for dietary fiber, neutral detergent fiber, non-starch polysaccharides in relation to animal nutrition. Symposium: Carbohydrate methodology, metabolism and nutritional implications in dairy cattle. J. Dairy Sci. 74:3583-3597.

Wildman, E. E., G. M. Jones, P. E. Wagner, R. L. Boman, H. F. Trout Jr., and T. N. Lesch. 1982. A dairy cow body condition scoring system and its relationship to selected production characteristics. J. Dairy Sci. 65:495-501.

Wood, K. M., S. I. Palmer, M. A. Steele, J. A. Metcalf, and G. B. Penner. 2015. The influence of age and weaning on permeability of the gastrointestinal tract in Holstein bull calves. J. Dairy Sci 98:7226-7237 